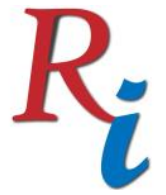

Asia Proceedings of Social Sciences

(APSS)

www.readersinsight.net/APSS

\title{
APPEAR IN COURT THRU VIDEO CONFERENCING SYSTEM: RECOMMENDATION FOR AN ISLAMIC FINANCE PERSPECTIVE Nur Khalidah Dahlan*
}

Faculty of Law

Universiti Kebangsaan Malaysia

Malaysia

*Corrosponding author's Email: nurkhalidahdahlan@ukm.edu.my

Peer-review under responsibility of $3^{\text {rd }}$ Asia International Multidisciplanry Conference 2019 editorial board (http://www.utm.my/asia/our-team/) (C) 2019 Published by Readers Insight Publisher, lat 306 Savoy Residencia, Block 3 F11/1,44000 Islamabad. Pakistan, info@ readersinsight.net This is an open access article under the CC BY-NC-ND license (http://creativecommons.org/licenses/by-nc-nd/4.0/). 


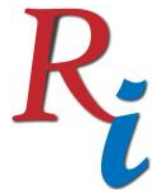

Asia Proceedings of Social Sciences

(APSS)

www.readersinsight.net/APSS

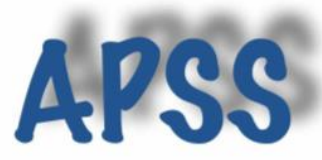

\section{Rese a r ch H i g h I igh t s}

Technologies applied in court is considered as a new type of method to settle dispute. Settlement of any dispute thru technology in court shall benefit all; Judges, Lawyers and parties concerned. Malaysian court especially in Sabah and Sarawak have dealt civil dispute cases thru technology approach. These development shows promising ways to decrease backlog cases that had been experienced in courts throughout the years. Hence, this paper suggested that the technology method apply in civil court particularly in Sabah and Sarawak court should adopted too in the Islamic finance disputes. It is important for everyone's future that we study the current technology in order to develop more effective settlement for Islamic Finance dispute for Malaysia.

\section{Research Objectives}

Courtroom technology is one of the ways in the future to draw attention to particular points, to emphasize certain aspects of the evidence and to make visible that which otherwise might only exist as a mental picture formed when words are spoken by an advocate or witness. According to Narkiewicz (2004), there are three levels of courtroom technology.

The video conferencing system applied in Malaysia was not the first court technologies being introduced. In Malaysia, the court technologies are called the 'E-court' system. The E-court system had been started implementing since March 2011. The four major systems in the ecourt system are Case Management Systems, Community and Advocate Portal Systems, Case Recording Transcription Systems and Tele/Video Conferencing Systems. The existence of this system is to overcome the problems and criticisms often associated with the system practiced by the courts nowadays as many of the cases had been overdue and had long-term trial processes. The existence of this system is expected to be able to manage with the problems often expressed by various complainants and dissatisfaction (Kamal Halili Hassan \& Maizatul Farisah Mohd Mokhtar, 2011).

Tele/video conferencing system (TVCS) had been applicable in east Malaysia mainly in Sabah and Sarawak. In respect of the use of TVCS it has benefited the public, lawyers and the courts in terms of costs and time savings due to the vast expanse of the territories. The TVCS is used for court hearing among the judges, lawyers and other persons involved in the session who are at different locations. This means judges and lawyers can save time and moneys travelling to and out of town. Lawyers can appear before a judge via tele/video conferencing in his hometown. TVCS also allows users to share documents, picture file, images etc. among those in remote locations, which constitutes a very vital feature for court hearings. TVCS is also now being used in case management hearings in which lawyers 'appear' in court from their offices. This is used mainly for non-contentious cases (Mohamed Nazri Abdul Aziz, 2009).

In the common practice, many lawyers and advocates in Sabah and Sarawak had to spend a lot of time in the road (to reach certain court locations) and yet the court trial is only take place about 30 minutes for a certain case. This difficulty has been solved by the presence of the tele/video conference system; It not only saves time but saves the cost of the parties involved. It is estimated that RM2,945 can be saved from any court trial using this system i.e. saving in terms of transportation fares, accommodation and related allowance claims (Kamal Halili Hassan \& Maizatul Farisah Mohd Mokhtar, 2011).

\section{Methodology:}

With such system lawyers need not have to wait unnecessarily long in courts for their cases to be called. They are only required to attend at the times allocated. Outstation lawyers are given 


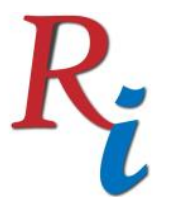

\section{Asia Proceedings of Social Sciences (APSS) \\ www.readersinsight.net/APSS}

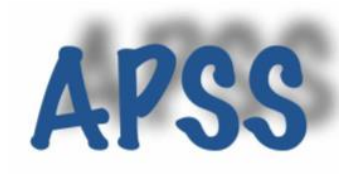

times that are convenient to them in term of in-coming flights. And for those lawyers who may have only one or two cases for that particular day they will be heard first. This also applies to those whose cases are coming up for settlement or adjournment.

To facilitate these, proceedings time is staggered at 9.00am, 10.00am and $11.00 \mathrm{am}$, and may extend to the afternoon hours for some cases, where necessary. Cases involving summons or notices which are unserved need not be called on the first mention day fixed, instead, new dates will be given. And, if no affidavit of service is filed with the Court one day before the scheduled dates, it will be assumed that the notices or summons have not been served. Where a matter has been fixed for mention for the third time, Counsel would have to appear and explain why it could not be served.

Divorce cases in the High Court are fixed on a particular day each week and are not mixed with other matters at the same time. This is to reduce as much as possible any discomfort a divorcing couple may have. Presently, the hearing for Video Conferencing is only for civil matters such as mentions, interlocutory applications such as injunctions, summary judgement, striking out defense, taxation, appeal before the judge in chamber. Relevant legislations must be in place before the Video Conferencing, it can be used for criminal matters and also for the hearings / trials for civil cases (Nur Khalidah Dahlan 2018).

\section{Results}

The jurisdiction of the Malaysian Shariah Court is limited by the Federal Constitution. In addition, there is no special jurisdiction for issues on Islamic Financial Transactions provided. Referring to the High Court Act 1964, the law civil matters, including matters related to Muamalat and Islamic Finance (Mohamad Azam Hussain, 2005).

In short, all Islamic finance cases will be trial under the Muamalat Court. The Muamalat Court has also similar jurisdiction with any of the High Court in Malaysia under the provisions of the Courts of Judicature Act 1964. There are existence of Court of Appeal for muamalat cases. These Muamalat appeal cases are categorized under the Full Trial Civil Appeals, in collateral with five other sub-categories which are the New Commercial Court Appeals, New Civil Court Appeals, Intellectual Property Appeals and Admiralty Appeals (The Malaysian Judiciary Yearbook, 2014).

Besides that, the jurisdiction of the Muamalat court also has to hear the case of specialization in Islamic banking and finance. In these courts, Shariah issues will be referred to the Shariah Advisory Council (SAC) of Bank Negara Malaysia. Reference to the SAC is based on Section 56 of the Central Bank Act, 2009, in which they will be the expert to decide on Shariah issues relating to Islamic banking and finance. Therefore, the establishment of the Muamalat court has made Malaysia the first country to have a court system that is structured to determine the principles of Shariah and legal issues in the field of Islamic finance.

In addition to that, there are also special code for Muamalat case that should be a reference and guidance to the courts and lawyers. It shows that the Muamalat cases should be treated differently from ordinary commercial cases. The classification code may be practical in the High Court in Kuala Lumpur and the Muamalat Courts, but still not effective at any other levels of the state in Malaysia. The special code for all Islamic banking and finance cases that are filed at the Muamalat Court at Kuala Lumpur High Court are Code 22M (previously Code 22A) for civil suits based on writ action and Code 22MF (previously Code 24A) for foreclosure matter and action based on originating summons. This Muamalat Court comprises of one High Court judge, one deputy registrar and one senior assistant registrar. Also, according to Ahmad 


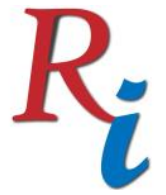

\section{Asia Proceedings of Social Sciences (APSS) \\ www.readersinsight.net/APSS}

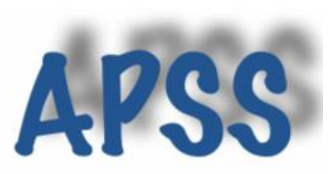

Hidayat Buang (2007), Muamalat court can specify a suitable solution since the core of the matter is the application of laws other than the Shariah in Islamic finance cases.

Due to that, technologies applied in civil court too can be adopted in the Islamic finance disputes. Settlement of any Islamic finance dispute thru technology in court also shall benefit all; Judges, Lawyers and parties concerned. It is important that the current court technology be apply in Islamic finance cases. It can develop more effective settlement for Islamic Finance dispute in Malaysia.

\section{Findings}

There are many advantages that can be seen when applying the court technology practice (Case Management Systems, Community and Advocate Portal Systems, Case Recording Transcription Systems and Tele/Video Conferencing Systems). Some of the advantages in applying the court technology is in the aspect of case settlement. Case settlement is much more efficient than the cases settled by common practice. $65 \%$ of cases are settled less than a year. Next advantage is the problem on case delay and case backlog matters can be solved. For example, the need of all the parties involve have to present during the trial can be substitute by applying the video conferencing technology. Other than that, the effect of applying technology in the court room had shown promising response from all. The Malaysian Court system, the practitioners and the society have created a sense of trust in the system due to the usage of ICTs that brought transparency to the overall court system (Wan Satirah Wan Mohd Saman \& Abrar Haider 2013).

\section{Acknowledgement}

This article is a part of the research outcome that is sponsored by The National University of Malaysia: 'Geran Galakan Penyelidik Muda' (Research Grant code: GGPM-2017-027).

\section{References}

Ahmad Hidayat Buang. (2007). Islamic Contracts in a Secular Court Setting: Lessons from Malaysia, Arab Law Quarterly 21 (2007) 317-340.

Kamal Halili Hassan \& Maizatul Farisah Mohd Mokhtar. (2011). Sistem E-Mahkamah Di Malaysia. [2011] 6 MLJ lii.

Menteri di Jabatan Perdana Menteri Datuk Seri Mohamed Nazri Abdul Aziz, Retrieved from http://penerangandppns.blogspot.com, 14 Ogos 2009

Mohammad Azam Hussain. (2005). Permasalahan Pelaksanaan Undang-Undang Muamalah Di Mahkamah Sivil. Dalam: Pengukuhan dan transformasi ekonomi \& kewangan Islam prosiding Seminar Ekonomi dan Kewangan Islam. ESSET Bangi. Jabatan Ekonomi Awam \& Kewangan, Fakulti Ekonomi, Universiti Utara Malaysia, Sintok, pp. 231-240. ISBN 983215586X. 29 - 30 Ogos (2005).

Nur Khalidah Dahlan, Mohd. Rizal Palil, Mohamad Abdul Hamid \& Noor Inayah Yaakub. (2017) Kaedah Penyelesaian Pertikaian Alternatif Dari Sudut Shariah Di Malaysia.aJournal of Nusantara Studies 2017, Vol 2(1) 86-98. Universiti Sultan Zainal Abidin. ISSN 0127-9386 (Online). (2017).

Nur Khalidah, Dahlan, Mohd Rizal, Palil, Noor Inayah, Yaa'kub \& Mohamad, Abdul Hamid. (2015). Islamic perspectives relating to business, arts, culture and communication. Proceedings of the 1st ICIBACC 2014. ISBN 978-981-287-428-3. ISBN 978-981-287-429-0 (eBook) DOI 10.1007/978-981-287-429-0. (2015). Springer Science \& Business Media Singapore Pte Ltd.

Tun Zaki Tun Azmi. (2010). Using Technology to Improve Court Performance: Malaysia Experience. Asia Pasific Judicial Reform Forum (2010), Beijing.

Wan Satirah Wan Mohd Saman \& Abrar Haider. (2013). E-Shariah: Information and Communication Technologies For Shariah Court Management. Legal Information Management, 13 (2013), pp. 94-106. 